DR JOHN COKLEY is a lecturer in journalism at the University of Queensland, Brisbane.

\section{Challenging the critical impact of the internet}

New Media, Old News: Journalism and Democracy in the Digital Age, edited by Natalie Fenton. London: Sage. 2009, 220 pp. ISBN: 978-1-847875-74-7.

$\mathrm{T}$

HERE ARE many in journalism, in both the academy and in practice, who on reading New Media, Old News, will shout, 'See, I told you so!' because the conclusions can be used to back up a very institutional, traditionalist approach to our profession. Others will vehemently disagree with the researchers' methods and conclusions, turning on them for presenting what was a large-scale, extensive and ambitious review of digital-age journalism in Britain which concludes, largely, that plus ça change. For me, as a researcher who teaches and continues to practise reporting and editing, this book is a difficult dish, rather challenging and exciting but-like my first Périgord black truffle-just a little disappointing.

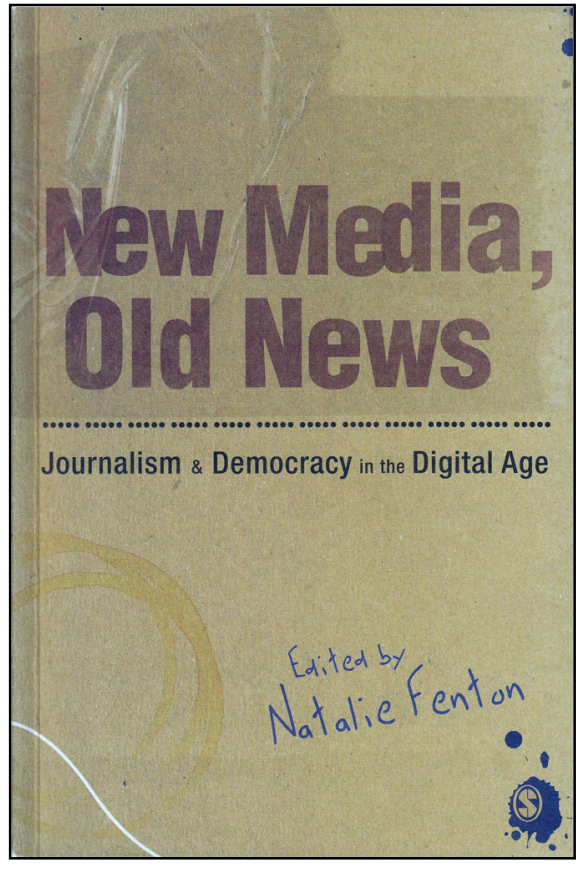

Challenging and exciting because it examines (in a Facebook kind of way) most of the areas I think journalism scholars should be investigating now, and the team from Goldsmiths at the University of London covers the literature quite comprehensively and even-handedly. There's a lot for me to cite in my own ongoing research. Disappointing? When the review copy arrived in my mailbox I dreaded the thought that the title might actually describe the contents accurately. It did.

Many of the chapters seem eager to challenge the impact of the internet and digital technologies on 
contemporary journalism even as the authors acknowledge that 'something big is happening'. It's like the climate change debate: ask people on any island in the South Pacific, or on any coastline in Australia (especially my own Queensland in 2011) whether climate change is happening and they'll vigorously agree. But just try to get general agreement on the reasons or the causes for climate change and the party splits up to all corners of the room.

How can this be? What were Natalie Fenton and her colleagues looking for? What did they miss? They have, as they acknowledge, used British case studies and the British journalism environment almost exclusively. So maybe nothing substantial is happening there? No: I spent two months of 2010 shuttling in and around Cardiff and London and a few ports further afield into the European Community and I'm here to vouch that something is indeed happening in journalism, mostly for and among people aged 25 and younger, mostly on alternative media blog and video sites, and ultimately in their pockets and on their phones.

But is the British journalism establishment - as many have confirmed for me-so hidebound in its local class structures that nine eminent scholars, two of them journalism practitioners, might have gazed off into the distance right over the top of Gen Y and concluded that all is definitely quiet on the western front? In Chapter 1, James Curran takes the lead by stressing 'the need for skeptical caution when assessing the impact of new communications technology' (p. 19). He suggests that 'the hyping of new technology sometimes took a form that served a neo-liberal political agenda' (p. 32). All this in an era when 'new technology' is hardly new any more, or even technical (requiring special knowledge to understand).

In Chapter 2, Des Freedman concludes that "predictions about the "end" of newspapers and the "collapse" of network news in the light of the dramatic shift online of audiences and advertisers miss out on a number of important points' (p. 47).

News organisations are not therefore about to lose entire swathes of readers and viewers as long as they continue to invest in original journalism and look for ways to make themselves relevant to audiences. (p. 49)

Freedman notes - with validity - that the drought of newspaper audiences started long before the Internet effects set in (p. 48). He also suggests-perhaps unwittingly harking back to Julianne Shultz's 1994 
edited volume Not Just Another Business - that 'the news industry is, by and large, not a normal industry' (p. 49)-this in itself a hotly contested matter and not at all settled in 2011. But worst of all, he offers no constructive outcomes of his research to suggest a way forward. What we need is recognition of an issue and researchers to take the issue forward, please.

In the same un-deconstructed way, Angela Phillips, Nick Couldry and Freedman in Chapter 3 fail to attempt to unpack what ethics might mean for the contemporary journalist but prefer- because it is an approach with which we are familiar' - a neoAristotelian attack which they use to assert that 'journalism matters', that 'we (society) need news media that ... help us sustain a successful, indeed peaceful, life together' and that 'journalism is a practice which is directed towards the circulation of necessary information' (p. 53).

Not everything is bad in New Media, Old News, as I mentioned at the beginning. Peter Lee-Wright's Chapter 4 foray into BBC online newsrooms uncovers some very useful points, principally by talking to working journalists. Angela Phillips correctly points out in Chapter 5 that many Big Media news websites cannibalise content and that you can get the same new stories from umpteen different companies.

But she fails when she suggests that 'the only significant movement towards a broadening of sources and contacts is in the use of social networking sites, electoral rolls and online directories by journalists' ( $\mathrm{p}$. 100), referring to 'journalists' only in a mainstream establishment way. She also fails to highlight the $154,839,385$ blogs and Small Media news sites out there today ${ }^{1}$, many of which carry original news content, such as slashdot.org/ (news for nerds), www. askamum.co.uk/News/ (pregnancy, baby and parenting news) and of course www.indymedia.org/en/index. shtml (lots of alternative sources). I was heartened to encounter Joanna Redden and Tamara Witschge's references to alternative media, especially IndyMedia in Chapter 10 (p. 185).

James Curran and Tamara Witschge make the bold statement in Chapter 6 that 'the international public sphere does not exist ... because communication about public affairs has not been properly globalised: the most important source of news in much of the developed world is still television' (p. 103). In Chapter 7 Aeron Davis suggests that the 'expectation' that 'new media enhances communicative exchange and thus brings stronger forms of social 
capital' remains 'relatively unfulfilled' (p. 121). He continues (p. 122) that 'new media is equally likely to be a contributory factor in weakening communicative ties, social capital and public engagement'. Let's try all these assertions on the new battalions of bloggers in Malaysia and the texting, Facebooking protesters in Tunisia and Egypt as I write this review.

Consider the book's often pejorative or patronising references to citizen journalists as 'self-appointed' (p. 85), 'de-professionalised' (p. 10), non-professional (p. 14) (see also pp. 50 and 123) and as outsiders, as Nick Couldry writes: 'Outside mainstream UK media institutions' (p. 138). Look here, old chap, I appointed myself as a journalist in 1981 when I decided (on my own as an impetuous young upstart) to enter this profession and began to sell my work on commission, and then my labour for a steady salary. I undertook university studies in reporting and editing (among other subjects). I worked as an ordinary journalist, moving from business to business when I felt like it. Everyone I know in journalism is a self-appointed journalist!

Thank goodness for Chapter 11, the final chapter, by Rodney Benson, who was commissioned by the other authors to critique their work in plain sight. Benson, from New York
University, is the only contributor not from Goldsmiths College at the University of London, and the only contributor who takes a determinedly non-UK viewpoint. His is a more important chapter than most, especially for readers of PJR, because it raises the 'other' questions not considered by the Goldsmiths team. He openly and positively addresses the book's deep deficiencies by writing 'to what extent does this portrait of the UK also hold for the US, the rest of Western Europe, and indeed, the rest of the world?' (p. 187).

Benson ends his chapter looking forward, seeking connections between institutional media and alternative media. He also notes - he agrees with the other contributorsthat while investment represents an answer to media issues, 'an open mind may be just as important as money' (p. 199).

\section{Note}

1. http://blogpulse.com/. Retrieved on 2 February 2011.

\section{Reference}

Schultz, J. (Ed.) (1994). Not just another business. Sydney: Pluto Press. 